This PDF is a selection from a published volume from the National Bureau of Economic Research

Volume Title: International Trade in Services and Intangibles in the Era of Globalization

Volume Author/Editor: Marshall Reinsdorf and Matthew J. Slaughter, editors

Volume Publisher: University of Chicago Press

Volume ISBN: 978-0-226-70959-8; 0-226-70959-0

Volume URL: http://www.nber.org/books/rein09-1

Conference Date: April 28-29, 2006

Publication Date: May 2009

Chapter Title: Outsourcing and Imported Services in BEA's Industry Accounts

Chapter Author: Robert E. Yuskavage, Erich H. Strassner, Gabriel W. Medeiros

Chapter URL: http://www.nber.org/chapters/c11612

Chapter pages in book: (247 - 283) 


\title{
Outsourcing and Imported Services in BEA's Industry Accounts
}

\author{
Robert E. Yuskavage, Erich H. Strassner, and \\ Gabriel W. Medeiros
}

\subsection{Introduction}

Outsourcing of professional and support services by U.S. firms, especially goods-producing firms, is one of the factors that has contributed to the steady increase in the service sector's share of the U.S. economy. Outsourced services typically include software production, information and data processing services, computer systems design, professional, scientific, and technical services, and administrative and support services. The impact of the outsourcing trend is clearly seen in the growth of the domestic professional and business services sector, whose value-added share of gross domestic product (GDP) increased from 8.7 percent in 1987 to 11.6 percent in 2000 .

After 2000, however, growth slowed sharply in this outsourcing supply sector, with its share of GDP declining to 11.3 percent in 2003 before rebounding to 11.5 percent in 2004 . While it is possible that the growth of outsourcing itself slowed during the economic downturn, another possible explanation is that U.S. firms started to substitute imported services for domestic services as part of their outsourcing strategy, thus reducing demand for domestic outsourcing services. In recent years, imports of business, professional, and technical services, while still relatively low, have increased faster than domestic production of similar services. This faster growth may

Robert E. Yuskavage is a senior economist in the office of the Associate Director for Industry Accounts at the Bureau of Economic Analysis. Erich H. Strassner is the chief of the Industry Research Group at the Bureau of Economic Analysis. Gabriel W. Medeiros is an economist in the Industry Research Group at the Bureau of Economic Analysis.

The authors thank Maria Borga, Karen Horowitz, Ned Howenstine, Doug Meade, Sue Okubo, Mark Planting, George Smith, and Obie Whichard, of BEA, for helpful comments on the paper. 
be related to the offshore outsourcing development that has received much attention recently from the media, economists, and policymakers.

The growing importance of international transactions in services, especially services enabled by information and communications technology, has also raised questions about the effects of offshore outsourcing on U.S. economic growth, its impact on the output and employment of domestic industries, and the implications for productivity growth. Outsourcing as an economic activity is fundamentally about industry production technology and how business establishments adjust their mix of inputs in response to changes in demand, relative prices, and technology, so it is best studied at the industry level, using time series data on industry output, inputs, and prices. Detailed industry data at the establishment level are important because of the different ways in which producers can meet their needs for inputs of professional and support services. ${ }^{1}$ These needs can be met internally (within the establishment), using their own resources, or externally, by contracting out or through other arrangements. External suppliers can be affiliated, either as domestic auxiliaries or foreign affiliates, or they can be unaffiliated, independent domestic or foreign entities. ${ }^{2}$ Regardless of supplier affiliation or location, industry data on input cost categories such as energy, materials, and purchased services, combined with data on labor and capital inputs, can help identify the industries that engage in outsourcing and to study how and why outsourcing occurs.

Empirical evidence on the dimensions of outsourcing is quite limited, especially evidence needed to assess the impact of offshore outsourcing on domestic industries. The Bureau of Economic Analysis's (BEA) annual industry accounts, however, provide some insights into how outsourcing affects domestic industries. These accounts provide consistent time series data on the composition of gross output, intermediate inputs, and value added, including quantity and price indexes, for establishment-based industries classified according to the 1997 North American Industry Classification System (NAICS). The detailed time series data are available starting in 1997 and recently were expanded to include estimates of energy, materials, and purchased services intermediate inputs by industry. For this chapter, estimates of the imported portion of purchased services by industry were also developed.

Studies of offshore outsourcing by U.S. firms have primarily addressed its impact on economy-wide measures such as GDP, the balance of pay-

1. Establishments are units, such as a plant, mine, store, or office, where productive activities occur. They are classified by industry according to their primary activity. Different establishments owned by the same company can be classified in different industries.

2. Some authors, including van Welsum and Reif (this volume), classify transactions between affiliated parties as "insourcing" rather than outsourcing. This distinction is not important for our purposes, so for convenience, we use outsourcing to mean all purchases of offshored services. See Olsen for a discussion of this issue. 
ments, aggregate employment, and business sector productivity (Borga 2005; Government Accountability Office 2004; Kozlow and Borga 2004). Some studies, though, have examined its impact on domestic industries by identifying the occupations that are most affected by outsourcing and determining which industries tend to employ those occupations (e.g., van Welsum and Reif 2005). One study took a different approach, by identifying the domestic industries that were most engaged in providing tradable services that went beyond local markets, and that were thus subject to import competition (Jensen and Kletzer 2005). Studies that address the impact of offshore outsourcing on industry productivity are summarized by Olsen (2006).

This chapter extends the focus on industries by identifying industries that engage in outsourcing and the degree to which their outsourcing needs are met by offshore suppliers. The objectives of this chapter include:

- Explaining the treatment of imported services in BEA's international, national, and industry accounts

- Describing BEA's new framework for measuring purchased services in the industry accounts, including the role of the integrated industry accounts

- Identifying the growth of purchased services as an intermediate input and the effect of imports on that growth, and

- Describing research that uses BEA company data to improve the estimates of imported purchased services by industry.

\subsubsection{Overview of Findings}

Imports of services in the U.S. economy exceeded \$300 billion in 2004 and accounted for nearly 17 percent of total U.S. imports of goods and services. Imports of business, professional, and technical services, the category in BEA's international transactions accounts most closely associated with outsourcing, increased rapidly after 1997 but still only accounted for about 15 percent of imported services. Moreover, only about 30 percent of these outsourcing-related services are currently classified in BEA's industry accounts as comparable to domestic production, and thus able to compete with similar domestic services in the outsourcing market.

In BEA's industry accounts, imports of intermediate purchased services were also relatively small, but they steadily increased as a share of total intermediate purchased services, rising from 2.9 percent in 1997 to 3.6 percent in 2004. Purchased services include those that are closely associated with outsourcing, such as computer, engineering, and accounting services, but also include other purchased services, such as utilities, transportation, communications, finance, and insurance. Outsourcing-related services overall increased as a share of total services purchased by business, rising from 30.8 percent in 1997 to 33.9 percent in 2004. The share of outsourcing- 
related services attributable to imports also increased during this period, rising from 2.1 percent to 2.7 percent.

The small size of these imported services, especially those currently classified in the industry accounts as competing with domestic production, suggests that import competition played only a small role in the slower growth of the domestic professional and business services (outsourcing) sector after 2000. Slower real output growth and declining employment in this sector are probably better explained by the downturn of 2001 and the decline in demand for certain types of information and communications technology. Further study is required, though, to develop a better understanding of how imported services affect industry output, employment, and contributions to GDP. More research is also needed to determine the sensitivity of these results as to how imported services are classified and distributed in the industry accounts.

\subsubsection{Outline of the Chapter}

The remainder of this chapter is presented in four sections. Section 8.2 discusses the treatment of imports, particularly imported services, in BEA's international, national, and industry accounts. Section 8.3 discusses the treatment of purchased services generally in BEA's productionoriented industry accounts, how outsourcing-related services are defined, and how imported services are handled within this framework. This section also includes empirical results on the industry distributions of imported services and the contribution of imports to outsourcing. Section 8.4 presents an evaluation of the methodology based on unpublished data from BEA's international accounts, and offers some suggestions for improving the industry estimates of imported purchased services. Section 8.5 is a summary and conclusion.

\subsection{Imports in BEA's Accounts}

This section provides an overview of how imported services are defined and classified in BEA's international, national, and industry accounts. It begins with the international transactions accounts (ITAs), where these transactions are initially recorded, proceeds to the national income and product accounts (NIPAs), and then concludes with the annual industry accounts (AIAs). Differences among these accounts in concepts and coverage are described and the relationships among the flows in the accounts are briefly explained. An understanding of the relationships among these three accounts is important, because imported services first appear in the ITAs before showing up in the NIPAs and then in the industry accounts.

\subsubsection{International Transactions Accounts}

The BEA's international transactions accounts (ITAs) provide monthly, quarterly, and annual estimates of transactions between U.S. and foreign 
residents. ${ }^{3}$ The ITAs include a current account, a capital account, and a financial account. The two major components of the current account are (a) exports of goods and services and factor income receipts and (b) imports of goods and services and factor income payments. The difference between these two components, plus net unilateral current transfers, equals the balance on current account. The capital account includes capital transfers, such as debt forgiveness. The two major components of the financial account are (a) changes in net U.S.-owned assets abroad and (b) changes in net foreign-owned assets in the United States. These components are the major source of change in the U.S. net international investment position.

Imports of services in the current account are estimated from a variety of sources, primarily BEA's own direct investment surveys of U.S. and foreign multinational companies (MNCs) and BEA's surveys of U.S. international services transactions between unaffiliated parties. Quarterly and annual estimates of imported services are published for seven broad categories that represent types of services transactions. These categories are direct defense expenditures, travel, passenger fares, other transportation, royalties and license fees, other private services, and U.S. government miscellaneous services. Direct defense expenditures include some goods (mainly materials), supplies, and petroleum products purchased abroad by U.S. military agencies. Other transportation includes some fuels purchased by airline and steamship operators. Additional detail is provided annually.

The BEA's direct investment surveys are mandatory and collect selected data for transactions between the U.S. parents of multinational companies and their foreign affiliates and transactions between the U.S. affiliates of foreign MNCs and their foreign parent companies and certain other affiliated foreign firms. These data play an important role in compiling the ITAs and are complemented with data on transactions between unaffiliated parties to provide a full picture of U.S. international transactions. Because U.S. MNCs are typically very large firms, the combined data for U.S. parents and U.S. affiliates of foreign MNCs account for a significant share of domestic economic activity, especially in the goods-producing sector of the economy. These combined company data, when classified by industry, provide valuable insights into the industry distribution of imported purchased services and are discussed in more detail in section 8.4.

\subsubsection{National Income and Product Accounts}

The BEA's national income and product accounts (NIPAs) provide quarterly and annual estimates of U.S. production, income, consumption, investment, and saving. The NIPAs include subaccounts for domestic

3. Transactions between the United States and its territories, Puerto Rico, and the Northern Mariana Islands are not treated as foreign transactions in the ITAs. 


\begin{tabular}{lr}
\hline Imports of services & 301.9 \\
Direct defense expenditures & 29.3 \\
Travel & 65.6 \\
Passenger fares & 23.7 \\
Other transportation & 54.2 \\
Royalties and license fees & 23.9 \\
Other private services & 95.7 \\
Other imports of services & 9.5 \\
\hline
\end{tabular}

Note: Exports of services were \$355.7 billion in 2004.

product and income, personal income and outlays, government current receipts and expenditures, foreign transactions, and saving and investment. The featured measure from these accounts is GDP, which is a measure of the market value of final goods and services produced in a period. The major categories of final expenditures, which sum to GDP, are personal consumption expenditures, gross private domestic investment, net exports of goods and services, and government consumption expenditures and gross investment.

Net exports are defined as exports less imports. Estimates of trade in goods and services are provided separately for exports and for imports. In calculating GDP as the sum of final expenditures, all imports are subtracted without regard to whether they are consumed in final uses (e.g., as personal consumption expenditures) or in intermediate uses by U.S. industries (e.g., as purchased services or materials). Current-dollar (nominal) imports in the NIPAs are valued in the prices paid to foreign suppliers (foreign port value), which exclude import duties and transportation and insurance costs needed to reach the United States. Quantity and price indexes are prepared quarterly and annually for both exports and imports.

Foreign transactions in the NIPAs are shown in more detail for goods and for services in several of its subaccounts. Imports of services in the NIPAs are slightly larger than in the ITAs, mostly because of a territorial adjustment in the NIPAs that treats purchases by U.S. residents from U.S. territories and Puerto Rico as imports rather than as transactions between domestic parties. Imports of services are shown in NIPA subaccounts for the same seven broad categories of transactions that appear quarterly in the ITAs, except for an "other" category that includes the territorial adjustment. The NIPA foreign transactions subaccounts also provide quantity and price indexes for the seven categories of imported services. Table 8.1 shows the nominal values for these imported services categories for $2004 .^{4}$

4. Estimates provided in this chapter do not include the results of the annual revision of the NIPAs released in July 2006. 


\subsubsection{Annual Industry Accounts}

BEA's annual industry accounts (AIAs) include the integrated GDPby-industry and annual input-output (I-O) accounts. In these accounts, industries are defined according to the North American Industry Classification System (NAICS). Estimates are published for sixty-one private industries and for four government classifications. The GDP-by-industry accounts feature nominal and real value added by industry estimates. Value added is defined as an industry's gross output (sales or receipts and other operating income) minus its intermediate inputs (energy, materials, and purchased services). Intermediate inputs are acquired from either domestic or foreign sources (imports). Price and quantity indexes of gross output, intermediate inputs, and value added are published for industries, industry groups, and broad sectors in the GDP-by-industry accounts.

The annual I-O accounts provide a time series of detailed, consistent information on the flows of goods and services that comprise industry production processes and that are included in final expenditures. These accounts are presented in standard make-and-use tables and several supplementary tables, and they provide more detail than the GDP-byindustry accounts on the commodities included in gross output and intermediate inputs. The make table shows the commodities (goods and services) that are produced by each industry. The use table shows the commodity inputs to industry production and the commodities that are consumed by final users (see table 8.2).

Commodities are shown along the rows of the use table, and industries and final uses are shown in the columns. Total commodity output (in the right-most column) represents total domestic production of each commodity. The total domestic supply of each commodity (not shown) is the sum of total commodity output less exports of goods and services less imports of goods and services (recorded as negative values) less the change in private inventories. In the industry accounts methodology, commodity supply is distributed to (and completely exhausted) in final uses (GDP) and in intermediate uses by industries. Because final and intermediate uses include imports, the negative values in the imports column ensure that all imports, regardless of use, are subtracted in the final uses measure of GDP.

The commodity composition of imports is calculated as part of the AIAs. Import categories from the NIPAs for both goods and services are disaggregated and distributed among the detailed commodities that comprise the rows of the I-O use table. This distribution closely follows that from the most recent benchmark I-O accounts, which are prepared every five years using detailed data from the economic censuses and other sources. When the domestic supply of detailed commodities, including imports, is allocated among final and intermediate uses, however, no distinction is made based on the source of the commodity. As a result, the values 


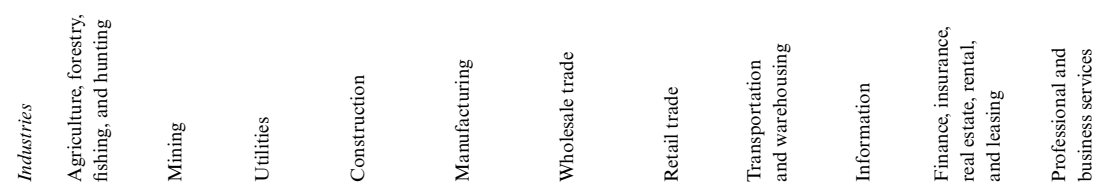

\begin{tabular}{|c|c|c|c|c|c|c|c|c|c|c|c|}
\hline \multicolumn{12}{|l|}{ Commodities } \\
\hline $\begin{array}{l}\text { Agriculture, for- } \\
\text { estry, fishing, and }\end{array}$ & & & & & & & & & & & \\
\hline hunting & 73,612 & 1 & 10 & 1,024 & 173,064 & 3,052 & 394 & 9 & 12 & 1,452 & 5,903 \\
\hline Mining & 517 & 42,192 & 88,407 & 6,004 & 229,751 & 34 & 23 & 6,283 & 1 & 1,685 & 179 \\
\hline Utilities & 5,680 & 2,616 & 174 & 3,110 & 50,223 & 6,786 & 16,176 & 3,206 & 4,911 & 43,073 & 16,644 \\
\hline Construction & 1,443 & 67 & 2,226 & 1,000 & 8,139 & 2,552 & 5,475 & 1,511 & 2,998 & 30,027 & 9,875 \\
\hline Manufacturing & 51,068 & 27,690 & 7,367 & 241,656 & $1,405,324$ & 55,902 & 73,900 & 75,433 & 72,256 & 91,859 & 89,667 \\
\hline Wholesale trade & 11,418 & 4,494 & 1,457 & 30,131 & 261,318 & 30,624 & 10,207 & 16,405 & 13,641 & 11,269 & 14,670 \\
\hline Retail trade & 149 & 424 & 74 & 68,130 & 13,783 & 3,153 & 5,697 & 2,638 & 817 & 13,543 & 9,628 \\
\hline Transportation and & & & & & & & & & & & \\
\hline warehousing & 7,454 & 6,778 & 22,886 & 15,434 & 125,974 & 17,250 & 22,731 & 73,268 & 9,945 & 27,649 & 25,689 \\
\hline Information & 1,146 & 737 & 317 & 9,673 & 39,960 & 17,148 & 20,114 & 9,416 & 217,972 & 30,704 & 83,235 \\
\hline $\begin{array}{l}\text { Finance, insurance, } \\
\text { real estate, rental, } \\
\text { and leasing }\end{array}$ & 15,751 & 23,344 & 4,217 & 31,898 & 117,555 & 51,604 & 98,117 & 33,021 & 69,088 & 639,982 & 142,300 \\
\hline $\begin{array}{l}\text { Professional and } \\
\text { business services }\end{array}$ & 5,213 & 22,974 & 4,665 & 78,989 & 337,727 & 104,861 & 162,238 & 53,292 & 128,400 & 237,878 & 330,260 \\
\hline $\begin{array}{c}\text { Educational services, } \\
\text { health care, and } \\
\text { social assistance }\end{array}$ & 17 & 91 & 275 & 117 & 3,235 & 881 & 682 & 548 & 2,527 & 1,131 & 2,618 \\
\hline $\begin{array}{l}\text { Arts, entertain- } \\
\text { ment, recreation, } \\
\text { accommodation, } \\
\text { and food services }\end{array}$ & 501 & 596 & 554 & 2,141 & 20,959 & 6,372 & 8,216 & 4,716 & 16,241 & 21,374 & 33,657 \\
\hline $\begin{array}{l}\text { Other services, } \\
\text { except govern- } \\
\text { ment }\end{array}$ & 3,209 & 437 & 411 & 9,907 & 48,527 & 9,076 & 10,127 & 8,102 & 15,379 & 24,307 & 26,569 \\
\hline Government & 111 & 54 & 174 & 1,136 & 3,157 & 4,149 & 5,790 & 1,047 & 4,672 & 9,006 & 14,549 \\
\hline Other inputs ${ }^{\mathrm{a}}$ & 95 & 1,862 & 30 & 611 & 32,304 & 14,861 & 695 & 18,610 & 9,403 & 22,843 & 6,524 \\
\hline $\begin{array}{l}\text { Scrap, used and } \\
\text { secondhand }\end{array}$ & & & & & & & & & & & \\
\hline goods & 1 & & 0 & 8 & 20,503 & 4 & 405 & 7 & 0 & -702 & 12 \\
\hline $\begin{array}{l}\text { Total intermediate } \\
\text { inputs }\end{array}$ & 177,383 & 134,354 & 133,246 & 500,967 & $2,891,501$ & 328,308 & 440,987 & 307,513 & 568,265 & $1,207,078$ & 811,979 \\
\hline $\begin{array}{l}\text { Compensation of } \\
\text { employees }\end{array}$ & 39,277 & 43,459 & 55,432 & 360,105 & 915,215 & 367,855 & 451,515 & 219,785 & 234,115 & 605,384 & 944,587 \\
\hline $\begin{array}{l}\text { Taxes on production } \\
\text { and imports, less } \\
\text { subsidies }\end{array}$ & $-4,285$ & 16,264 & 39,026 & 6,831 & 47,637 & 152,525 & 164,843 & 17,097 & 40,415 & 240,507 & 25,315 \\
\hline Gross operating & & & & & & & & & & & \\
\hline surplus & 106,629 & 112,161 & 140,804 & 182,570 & 457,270 & 174,361 & 174,042 & 96,026 & 264,209 & $1,566,992$ & 381,965 \\
\hline $\begin{array}{l}\text { Total value added } \\
\text { Total industry }\end{array}$ & 141,620 & 171,884 & 235,262 & 549,506 & $1,420,123$ & 694,741 & 790,400 & 332,908 & 538,739 & $2,412,884$ & $1,351,866$ \\
\hline output & 319,003 & 306,239 & 368,508 & $1,050,473$ & $4,311,624$ & $1,023,050$ & $1,231,387$ & 640,421 & $1,107,004$ & $3,619,962$ & $2,163,845$ \\
\hline
\end{tabular}

ancludes noncomparable imports, inventory valuation adjustment, and rest-of-the-world adjustments.

of intermediate inputs in the industry accounts include imports, but data are not available to indicate how much of intermediate consumption comes from imports.

An important part of the allocation of imported services to final uses or to the industries that use them as intermediate inputs is the translation of the ITA and NIPA import categories, which are primarily types of expenditures or transactions, into the commodity detail used in the productionoriented industry accounts. Detailed annual data on types of purchased 


\section{MIMIn!}

\begin{tabular}{|c|c|c|c|c|c|c|c|c|c|c|c|c|}
\hline 584 & 9,547 & 323 & 2,513 & 271,498 & 48,927 & & 1,197 & 28,202 & $-28,013$ & $-1,830$ & 48,483 & 319,981 \\
\hline 10 & 56 & 11 & 10,635 & 385,788 & 113 & 56,493 & 6,294 & 5,896 & $-166,451$ & 1,204 & $-96,451$ & 289,337 \\
\hline 11,887 & 16,875 & 6,248 & 47,529 & 235,140 & 205,236 & & & 1,054 & $-1,438$ & & 204,851 & 439,991 \\
\hline 8,867 & 6,714 & 3,464 & 48,783 & 133,140 & & 806,138 & & 69 & & 227,452 & $1,033,659$ & $1,166,800$ \\
\hline 124,318 & 112,134 & 67,205 & 246,894 & $2,742,672$ & $1,428,340$ & 619,523 & 79,954 & 566,131 & $-1,239,721$ & 98,871 & $1,553,098$ & $4,295,770$ \\
\hline 18,324 & 19,437 & 10,521 & 29,827 & 483,743 & 318,111 & 87,658 & 11,354 & 77,943 & 23,265 & 9,908 & 528,238 & $1,011,982$ \\
\hline 3,025 & 3,763 & 8,748 & 25 & 133,597 & 959,430 & 45,868 & & 1 & & & $1,005,299$ & $1,138,897$ \\
\hline 16,595 & 9,735 & 5,753 & 42,171 & 429,310 & 154,601 & 12,609 & 4,208 & 70,353 & $-13,164$ & 1,011 & 229,618 & 658,928 \\
\hline 37,813 & 18,735 & 14,068 & 67,270 & 568,307 & 295,314 & 57,648 & 1,808 & 26,260 & $-4,548$ & 7,917 & 384,398 & 952,705 \\
\hline 142,931 & 69,657 & 45,876 & 76,464 & $1,561,805$ & $1,870,437$ & 98,021 & & 92,228 & $-30,357$ & & $2,030,329$ & $3,592,134$ \\
\hline 138,006 & 52,800 & 45,050 & 251,386 & $1,953,738$ & 178,916 & 167,447 & & 71,811 & $-11,179$ & 25,173 & 432,168 & $2,385,906$ \\
\hline 12,814 & 515 & 721 & 36,931 & 63,100 & $1,610,637$ & & & 782 & -400 & & $1,611,019$ & $1,674,120$ \\
\hline 23,429 & 21,967 & 5,026 & 24,288 & 190,035 & 660,242 & & & 805 & -167 & & 660,880 & 850,915 \\
\hline 11,037 & 8,335 & 6,241 & 35,329 & 216,992 & 420,966 & & 46 & 182 & $-2,067$ & & 419,126 & 636,119 \\
\hline 14,757 & 3,317 & 3,724 & 9,130 & 74,772 & 53,260 & & & 257 & & $1,846,923$ & $1,900,439$ & $1,975,212$ \\
\hline 222 & 473 & 267 & 25,188 & 133,991 & $-38,351$ & -308 & $-53,650$ & 99,616 & $-193,971$ & -976 & $-187,641$ & $-53,650$ \\
\hline 2 & 3 & 713 & 13,177 & 34,133 & 48,118 & $-78,454$ & 4,222 & 10,483 & $-7,865$ & 266 & $-23,230$ & 10,902 \\
\hline 564,619 & 354,061 & 223,957 & 967,541 & $9,611,761$ & & & & & & & & \\
\hline 727,119 & 263,719 & 193,966 & $1,271,851$ & $6,693,383$ & & & & & & & & \\
\hline 10,687 & 48,487 & 18,691 & $-14,687$ & 809,353 & & & & & & & & \\
\hline 171,163 & 112,131 & 65,089 & 226,135 & $4,231,549$ & & & & & & & & \\
\hline 908,969 & 424,337 & 277,746 & $1,483,299$ & & & & & & & & $11,734,285$ & \\
\hline 473,588 & 778,398 & 501,703 & $2,450,840$ & & $8,214,296$ & $1,872,643$ & 55,432 & $1,052,072$ & $-1,676,077$ & $2,215,919$ & & $21,346,046$ \\
\hline
\end{tabular}

services are obtained from the company surveys conducted for the ITAs and are used to assign imported services to specific I-O commodities. These assignments may be straightforward, based on the nature of the service, or they may be indirect, with allocations made among several commodities based on historical relationships. For example, direct defense expenditures and other government services are allocated entirely to the government sector. The allocation of other categories, such as passenger fares and other transportation, is limited to a small number of transporta- 
tion services commodities. Payments for the cross-border transport of merchandise and U.S. import duties are included in the domestic port value of merchandise (goods) imports.

A significant portion of imported services, however, is treated in the industry accounts as not having a direct domestic counterpart, either because of the location of the service, its highly specialized nature, or because of the relationship of the supplier to the customer. These imports are currently classified as "noncomparable" in the industry accounts and are shown as a special commodity row in the use table. Examples of noncomparable imports include expenditures by U.S. residents on personal and business travel while abroad, port expenditures abroad by U.S. air and water transportation providers, certain royalties and license fees paid to foreign residents, and payments by U.S. firms to their foreign affiliates or to their foreign parents for unspecified services. While it is possible that some of the imported services that are currently classified as noncomparable have domestic counterparts, especially transactions between affiliated parties, the information available to BEA on the nature of the transaction is not detailed enough to determine the comparable domestic service.

Table 8.3 shows the translation of total imported services from the NIPAs to the annual industry accounts for 2004.

Because most imported goods now have domestic counterparts, noncomparable imports, which have accounted for about 70 percent of imported services in recent years, consist almost entirely of services. Before 1992, noncomparable imports included goods that had no significant domestic counterparts, such as bananas or coffee. Direct defense expenditures, travel, and royalties and license fees are classified entirely as noncomparable imports. Other private services and "other" services are distributed among a wider variety of comparable services, but large portions are treated as noncomparable imports. For example, nearly 80 percent of business, professional, and technical (BPT) services, the largest

Table 8.3 Translation of imported services in the NIPAs to comparable imported services in the annual industry accounts, 2004 (in billions of dollars)

\begin{tabular}{lr}
\hline Imports of services, NIPAs & 301.9 \\
Less: Coverage adjustment & 3.2 \\
Equals: Adjusted imports of services & 298.7 \\
Less: Transport and duty adjustment* & 64.7 \\
Equals: Imports of services, AIAs & 234.0 \\
Less: Noncomparable imports & 193.9 \\
Equals: Comparable services imports & 40.1 \\
\hline
\end{tabular}

*In the industry accounts, cross-border transport costs and import duties are included in the domestic port value of merchandise imports. Offsetting adjustments are made in wholesale trade and transportation services to ensure that total imports exclude import duties and transport costs paid to U.S. carriers, and that transport costs paid to foreign carriers are not counted twice. 
component of other private services, was classified as noncomparable in 2004, mostly because of the highly specialized or unspecified nature of the services provided by foreign affiliates to their U.S. parents or by foreign parents to their U.S. affiliates. ${ }^{5}$ All transactions in BPT services between unaffiliated parties, however, are classified as comparable services imports in the industry accounts.

\subsection{Purchased Services in BEA's Industry Accounts}

As described previously, BEA's annual industry accounts include the integrated GDP-by-industry and annual input-output (I-O) accounts. The annual I-O accounts provide a time series of detailed, consistent information on the flows of goods and services that comprise industry production processes and final expenditures. Estimates of the supply of commodities are prepared at nearly the same level of detail as in the benchmark I-O accounts, and are then aggregated to the less-detailed publication level used for the annual industry accounts. These time series are estimated within the framework of balanced make and use tables and are consistent with the NIPA estimates of final expenditures and industry estimates of gross output and value added. These additional layers of internal consistency in the annual industry accounts increase the overall reliability of the estimates of intermediate inputs by industry.

The AIAs were recently expanded to provide additional information on the composition of intermediate inputs by industry, allowing these accounts to be used to study trends in the use of purchased services inputs. The balanced I-O use table, which shows the commodity composition of intermediate inputs by industry and by final demand category, provides the product detail needed for aggregating estimates of intermediate inputs into cost categories that are useful for economic analysis. The product detail underlying the industry estimates of intermediate inputs has been aggregated into three cost categories - energy, materials, and purchased services. These estimates were prepared by applying a KLEMS production framework to BEA's estimates of industry production. ${ }^{6}$ Each of these three cost categories includes both imported and domestically produced goods and services. Intermediate inputs are valued in purchasers' prices, which include domestic transportation costs and wholesale trade margins plus sales and excise taxes.

5. Some imported services are classified as noncomparable partly because information is available for direct allocation to the using industries. Otherwise, they would be included in the domestic supply of a comparable commodity and allocated indirectly to using industries. The Bureau of Economic Analysis plans to evaluate this trade-off as part of an overall review of the treatment of imported purchased services in the industry accounts.

6. See Strassner, Medeiros, and Smith. For the most recently updated KLEMS estimates, see http://bea.gov/industry/gdpbyind_data.htm. 
The NAICS industry classification system that is used for the AIAs also provides advantages for studying outsourcing in the U.S. economy. The NAICS classification improves on the SIC as a classification system because it more consistently classifies establishments into industries on the basis of similar production processes, recognizes new and emerging industries, and provides greater detail for the services sector, which includes the industries that provide outsourcing services. Unlike the SIC system, NAICS provides separate industry groupings for information-related activities and for professional and business services. In addition, under NAICS, establishments that primarily provide support services to other establishments of the same company (i.e., auxiliaries) are classified according to the type of service they provide, rather than according to the industry of the establishments they serve, as they were under the SIC. Most such auxiliaries are classified in the NAICS professional and business services sector.

\subsubsection{Purchased Services Inputs}

The newly expanded AIAs allow the growth of services as intermediate inputs, including outsourcing-related purchased services, to be studied more closely after 1997 because, starting with that year, these accounts provide consistent time series data on gross output, intermediate input cost categories, value added, and price and quantity indexes. For the overall economy (all industries), purchased services increased as a share of gross output in each year from 1997 to 2003, before declining in 2004. The increases after 2000, however, were smaller than those between 1997 and 2000.

Purchased services inputs increased from 22.5 percent of gross output in 1997 to 24.8 percent in 2004. (See figure 8.1 and table 8.4.) Similar but less consistent trends appear for private goods-producing industries, which include manufacturing, and for private services-producing industries. For goods-producing industries, the purchased-services share increased from 15.1 percent in 1997 to 16.7 percent in 2002, but then it declined afterward. For services-producing industries, the purchased services share increased from 26.9 percent in 1997 to 29.7 percent in 2000 before declining in 2001 and then remaining flat.

The growth in purchased services inputs as a share of gross output after 1997 may have been due to faster growth in the relative prices of services inputs, faster growth in the use of purchased services relative to other inputs, or a combination of these two factors. Faster growth in the use of purchased services is a better indicator of possible outsourcing, because it implies changes in the production process rather than changes in relative input prices. The approximate contributions of these two factors can be found using the KLEMS-based price and quantity indexes. From 1997 to 2004, the quantity index of purchased-services inputs for all industries in- 


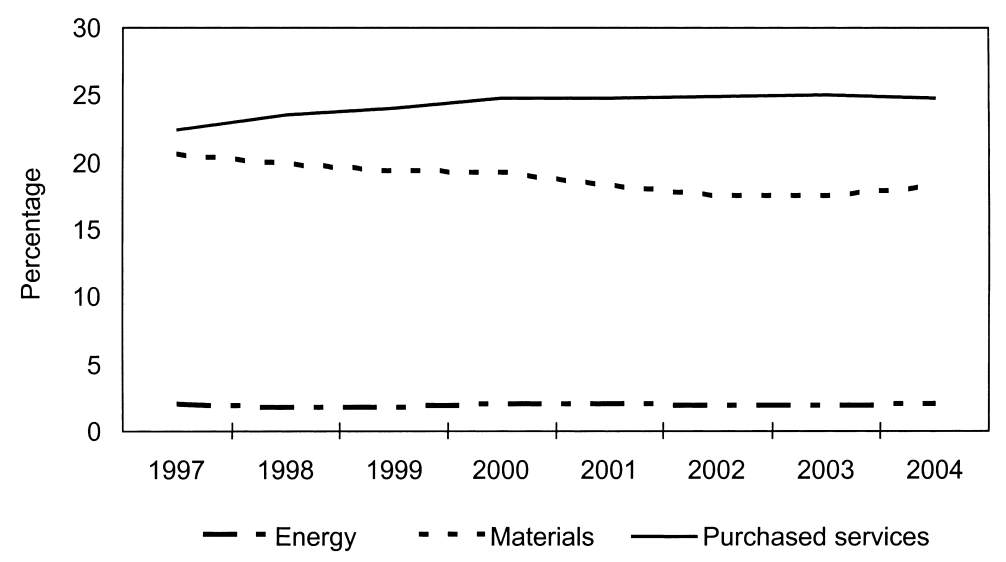

Fig. 8.1 Intermediate inputs as a percentage of all industries' gross output

creased at an average annual rate of 4.7 percent, compared to 3.2 percent for gross output, implying some substitution of purchased services for other inputs. Prices for purchased services inputs increased at about the same rate as gross output prices (1.7 percent). These results suggest that the growth in the share of purchased services reflects substitution among categories of inputs (i.e., changes in the production process) more than changes in the relative prices of inputs. Of course, the substitution toward purchased services may itself have been induced by changes in relative prices.

\section{Outsourcing-Related Purchased Services}

Not all of the growth in the output share of purchased services inputs is necessarily due to outsourcing, so it is useful to draw a distinction between outsourcing-related services and other types of purchased services. Because no consensus exists on exactly which types of purchased services constitute outsourcing, this study defines outsourcing-related services somewhat conservatively to include NAICS commodities 5112 (packaged software), 514 (information and data processing services), 54 (professional, scientific, and technical services), and 561 (administrative and support services). ${ }^{7}$ An important feature of each of these services is that more than one half of their domestic supply is used by the business sector, either as an intermediate input to production or as a form of business investment, such as capitalized software.

For the most part, these are the types of professional, technical, support,

7. Management of companies and enterprises (NAICS commodity code 55) was not included, mostly because there are no imports. This service could be included in a broader measure of outsourcing since it consists of management oversight services provided to other establishments of the same company. 


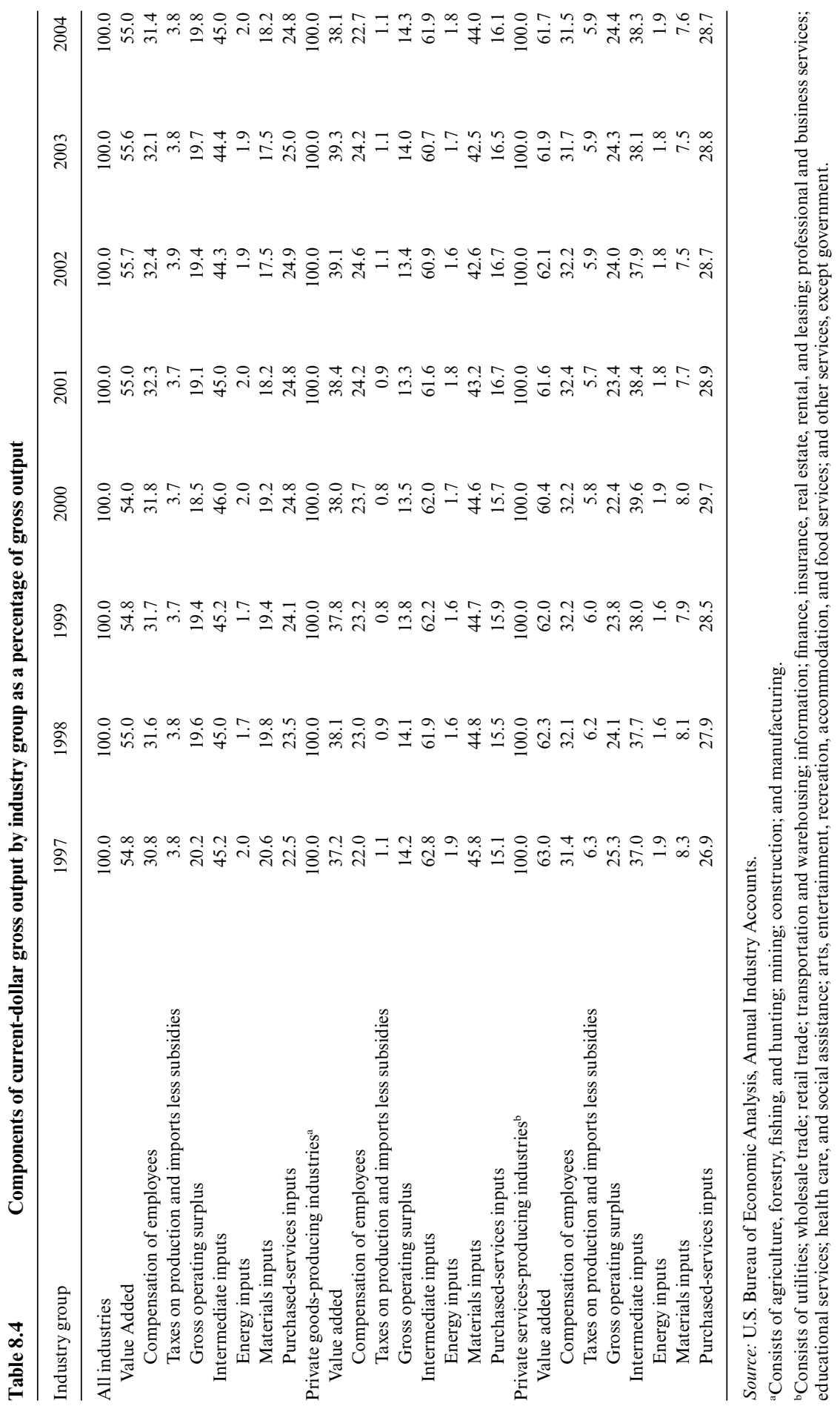


and administrative services that firms can choose either to provide within the same establishment using own-establishment employees or to acquire from external suppliers, either establishments owned by other companies or from their own domestic auxiliaries or foreign affiliates. Moreover, the outsourcing-related inputs defined previously are the types of services that are most vulnerable to import competition, because recent advances in information and communications technology have enabled foreign suppliers to provide these services more effectively and at lower cost. Other major types of services, such as utilities, communications, and finance, are not as likely to be performed within the establishment on an own-account basis.

In the remainder of this chapter, outsourcing-related services are referred to as business, professional, and technical (BPT) services. These services are defined to include the NAICS outsourcing-related services commodities, described previously, plus the portion of noncomparable imports identified as "other private services payments to affiliated foreigners." These noncomparable imports, which are very small relative to the total domestic supply of BPT services, are included because they consist largely of services that are similar in nature to the NAICS services commodities described earlier. Examples of these services include management consulting, public relations, research and development, and custom computer programming. ${ }^{8}$

The BPT services increased as a share of total purchased services, from 30.8 percent in 1997 to 33.9 percent in $2004 .^{9}$ This "outsourcing" share of purchased services varies by sector, ranging in 2004 from a high of 58 percent in construction to a low of nearly 7 percent in agriculture, forestry, fishing, and hunting. Among private industries, the second-highest outsourcing share of purchased services was in professional and business services (50 percent). The largest increase in the outsourcing share among private industries was in durable goods manufacturing, whose share rose from 31 percent in 1997 to 37 percent in 2004. Outsourcing-related services are clearly very important in the cost structure of many domestic industries, and they appear to be growing faster than other types of purchased services.

\subsubsection{Imported Services Inputs}

Purchased services, including outsourcing-related services, can be provided either by resident suppliers (domestic production) or by foreign suppliers (imports). The rapid growth of business, professional, and technical

8. Some argue that imports of BPT services from affiliates should not be treated as outsourcing because the transactions occur within the firm. Many of the underlying services, however, could have been performed by the U.S. establishment using its own resources or by other (unaffiliated) domestic establishments.

9. These shares were calculated using unpublished data from BEA's Annual Industry Accounts. 
Table 8.5

Imported business, professional, and technical services, industry accounts, 2004 (in billions of dollars)

$\begin{array}{cc}\text { Business, professional, and technical services } & 48.1^{*} \\ \text { Comparable imports } & 9.8 \\ \text { Purchased software and information services } & 0.2 \\ \text { Professional, scientific, and technical services } & 9.4 \\ \text { Administrative and support services } & 0.2 \\ \text { Noncomparable imports } & 38.3^{*}\end{array}$

*Includes $\$ 6.2$ billion in affiliated financial services. These services are not included in the ITA measure of BPT services.

(BPT) services imports in the ITAs suggests that offshore suppliers have contributed to the growth of purchased services and outsourcing in the U.S., and may have slightly gained market share at the expense of domestic suppliers. Imported services, however, are still very small compared to domestic production. For example, from 1997 to 2004, imported BPT services in the ITAs increased at an average annual rate of 10.1 percent, nearly doubling from $\$ 20.8$ billion to $\$ 40.7$ billion. By comparison, domestically produced professional and business services increased at an average annual rate of 6.3 percent, from $\$ 1,555.5$ billion to $\$ 2,385.9$ billion.

Table 8.5 shows the composition of imported BPT services in the industry accounts for 2004.

For this chapter, the authors disaggregated BEA's published KLEMSbased intermediate input cost categories to obtain estimates, by industry, of the imports included in each category, including purchased services. These annual import matrices were developed because of the lack of actual data on the use of comparable imports by industry. For each comparable commodity used by an industry, the portion attributable to imports was calculated as a percentage of the total purchase value, using the economywide share of imports in the total supply of the commodity. For example, if imports represent 40 percent of the domestic supply of semiconductors, then the import matrix estimates assume that imports comprise 40 percent of the value of semiconductors in each industry that uses semiconductors. These import shares were first developed for the benchmark use table using very detailed product data, and they were updated annually at the same level of product detail. ${ }^{10}$ Under this methodology, variation in the use of comparable imports by industry is due to variation in the commodity composition of intermediate inputs and variation in the commodity import shares.

10. The Bureau of Economic Analysis has prepared an import matrix for 1997 as a supplement to the 1997 benchmark I-O accounts using similar assumptions about the use of imported commodities. However, the valuation of imports in that matrix is slightly different. For more information, see the BEA website at http://www.bea.gov/industry/more.htm. 
Comparable imports at detailed product levels were aggregated, for each industry, into the broad category of purchased services, as defined for the KLEMS estimates, and into the narrower category of outsourcing-related BPT services, as previously defined for this chapter. Nearly all of the noncomparable imports were classified as purchased services in the KLEMS estimates, and a large portion of these were also classified as BPT services. Industry estimates of purchased services and of BPT services are the sums of the comparable and noncomparable imports assigned to these categories. The combined estimates are used in the following to identify the industries that import intermediate services, to describe how their use has changed since 1997, and to provide preliminary measures of the contribution of imports to total purchased services and BPT services.

\section{Industries Using Imported Services}

In the industry accounts, imported services for intermediate use increased from $\$ 98.5$ billion in 1997 to $\$ 188.2$ billion in 2004 . Imports as a share of intermediate purchased services, while still very low, increased from 2.9 percent to 3.6 percent over this period. The four largest imported services, which accounted for 95 percent of total imported intermediate purchased services in 2004, were noncomparable imports (70 percent), insurance carriers and related activities (16 percent), air transportation ( 5 percent), and miscellaneous professional, scientific, and technical services (4 percent). Imports of other transportation services and selected professional services accounted for the remainder.

Table 8.6 shows the dollar levels for the estimated imported purchased services by industry group for 1997 to 2004, and table 8.7 shows the percentage distribution of industry purchases of imported services. In 2004, finance and insurance consumed the most imported services $(\$ 45.0$ billion), followed by federal government ( $\$ 26.6$ billion), transportation and warehousing ( $\$ 23.6$ billion), durable goods manufacturing ( $\$ 17.7$ billion), and nondurable goods manufacturing ( $\$ 16.8$ billion). Table 8.7 indicates that some change took place in the industry distribution of imported purchased services over this period. Shares increased for the federal government and for finance and insurance and declined for transportation and warehousing and for information. Manufacturing's share decreased slightly after peaking in 2001 .

Another way of identifying industry groups that are significant users of imported purchased services is by examining the share of intermediate purchased services accounted for by imports. This "import intensity" is calculated by dividing an industry's imported purchased services by its total use of intermediate purchased services (table 8.8). In 2004, import intensities ranged from a high of 11.5 percent for transportation and warehousing to a low of 0.3 percent for health care and social assistance and for agriculture. Other private industry groups with relatively high import 


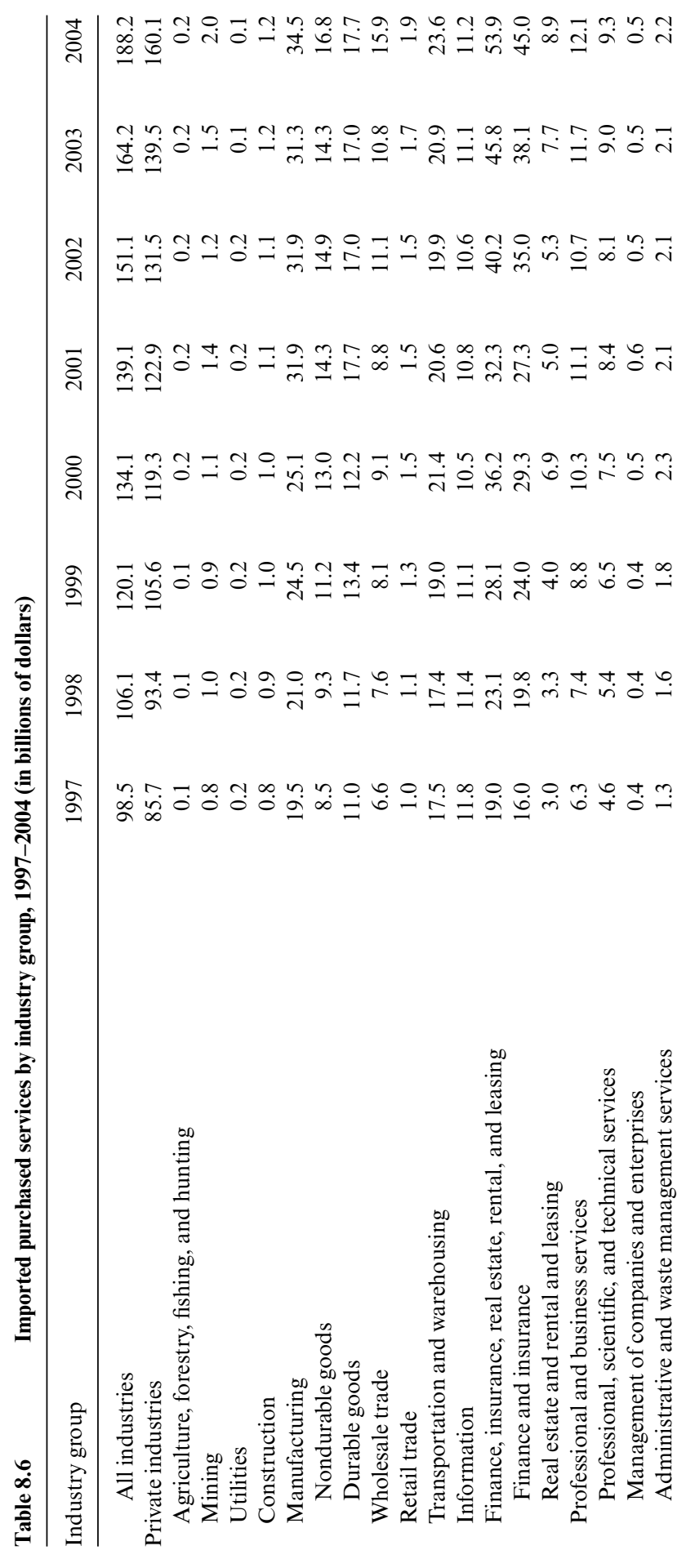




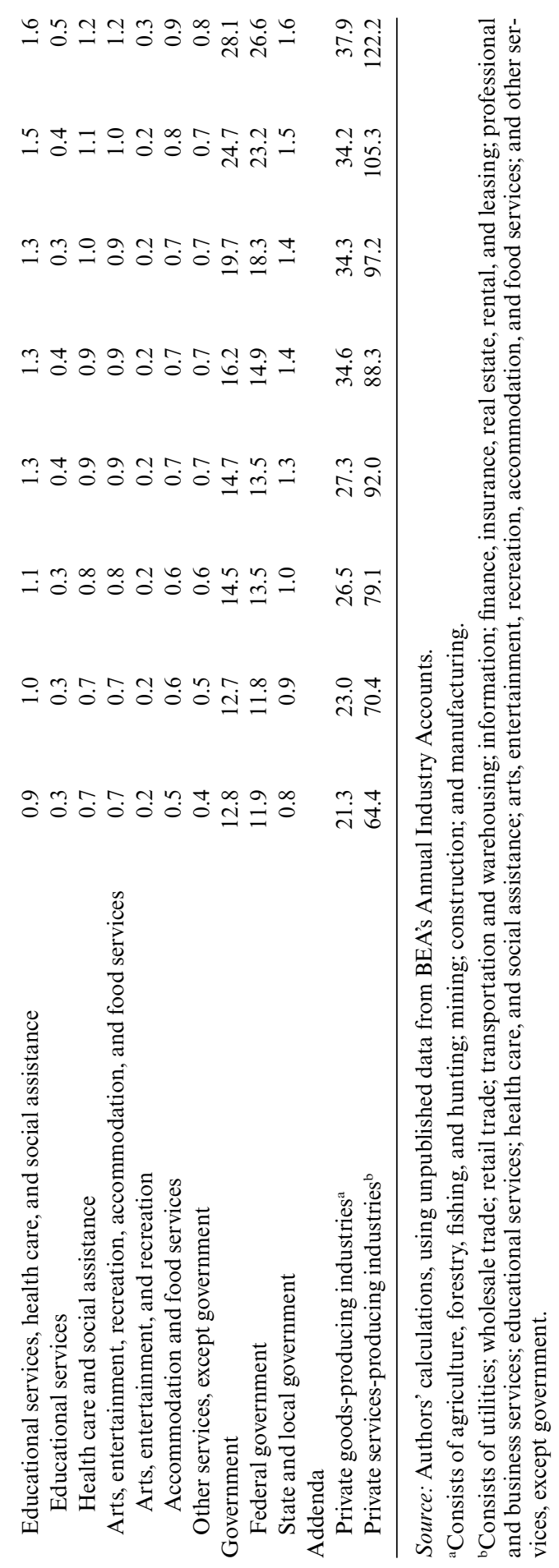




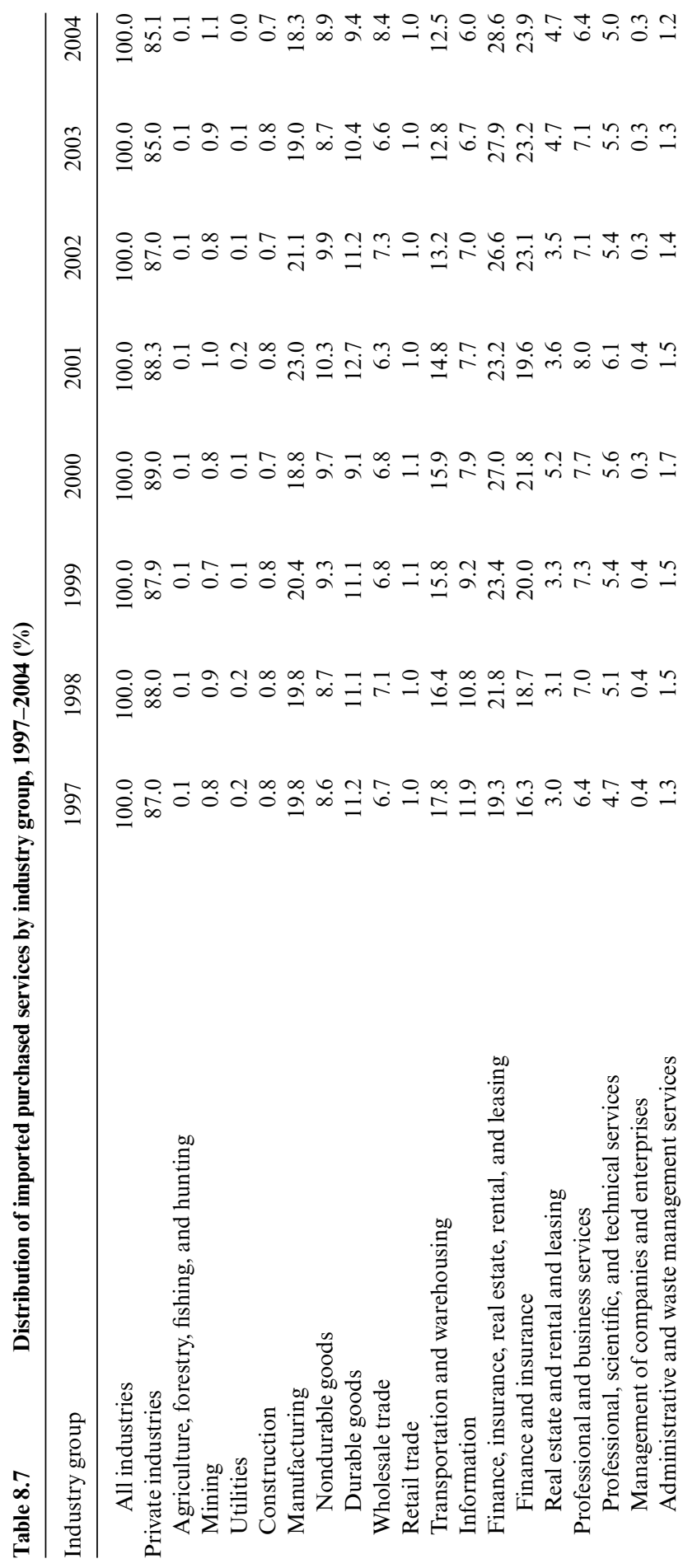




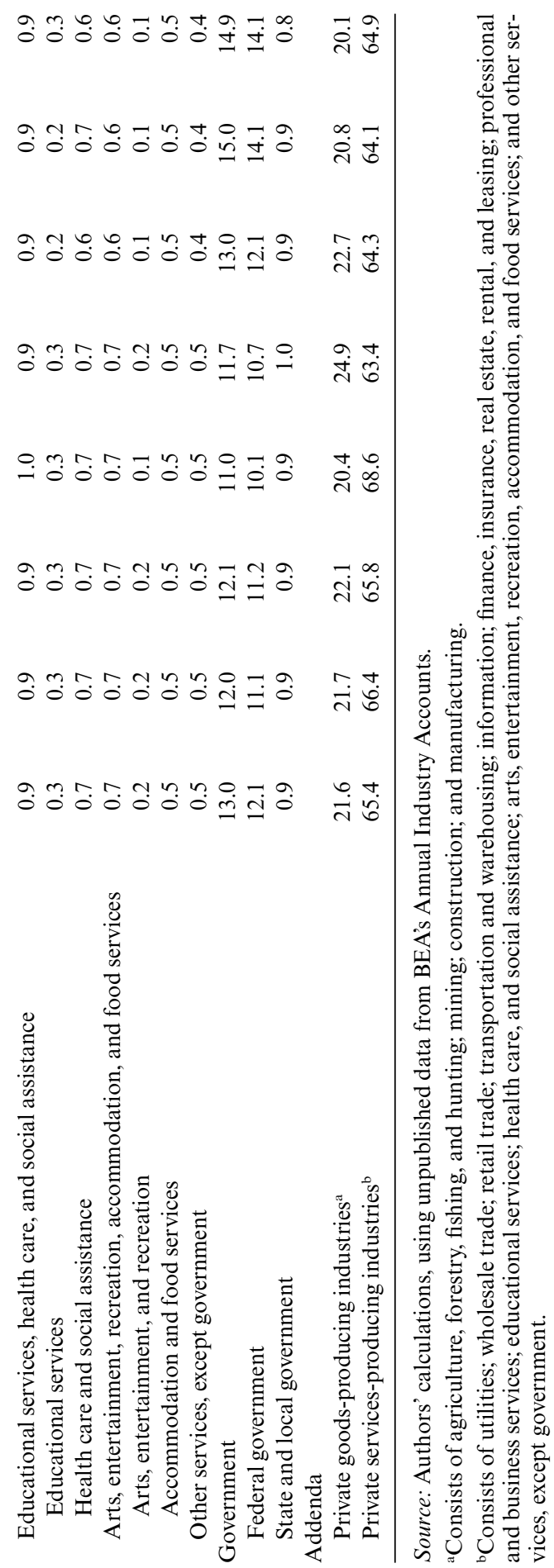




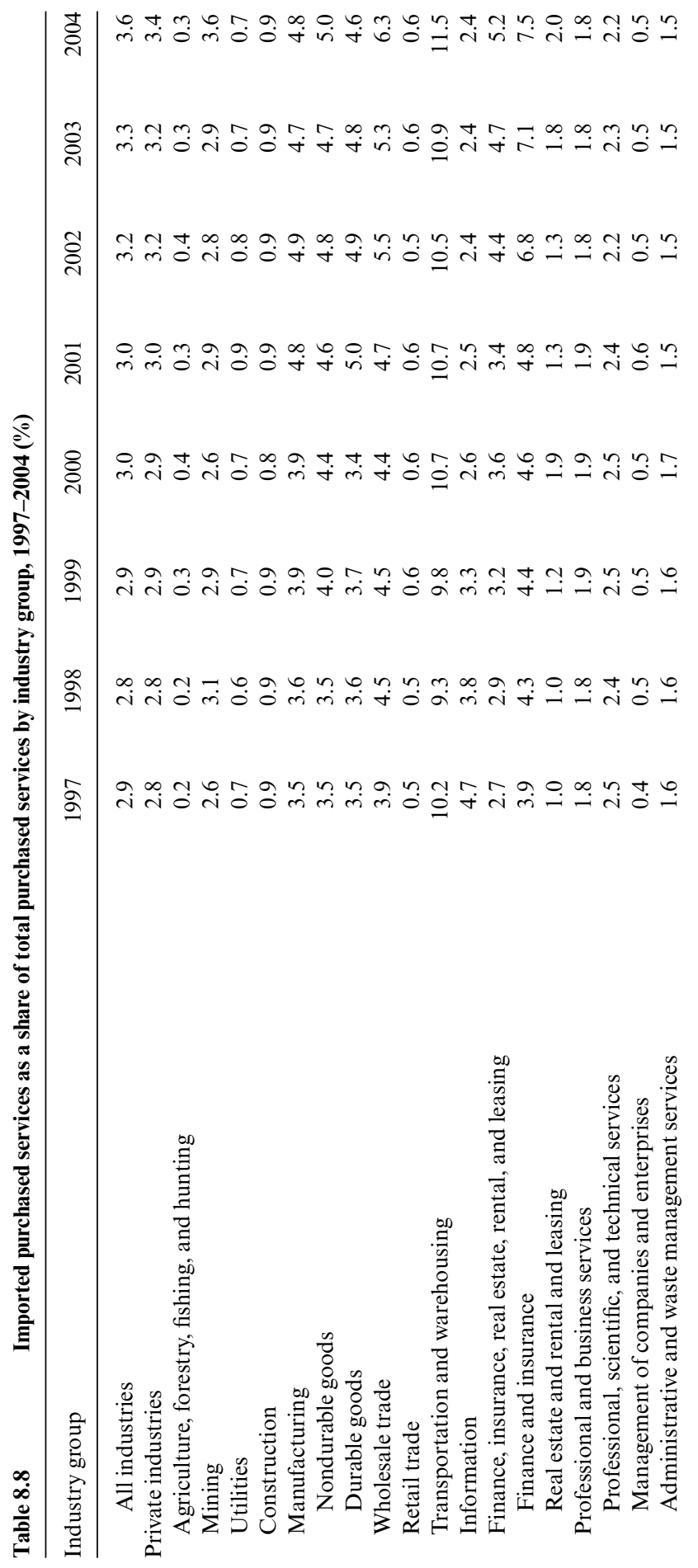




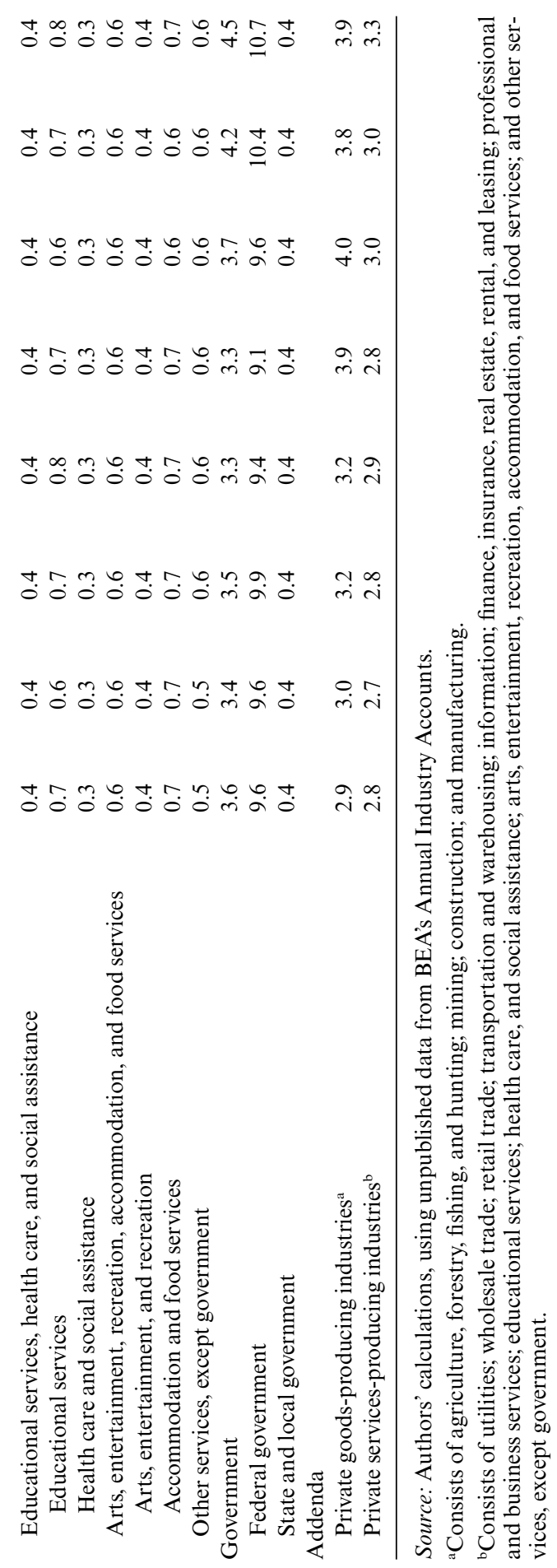


intensities include finance and insurance, wholesale trade, and manufacturing. Increases over time in the import intensity of purchased services may indicate that imported services are being substituted for domestic output.

\section{Industries Using Imported BPT Services}

In the industry accounts, imports of estimated BPT services increased from $\$ 22.0$ billion in 1997 to $\$ 48.1$ billion in 2004 (table 8.9). By 2004, BPT services accounted for slightly more than one fourth of all imported intermediate purchased services, up from 22 percent in 1997. Shares increased over this period for both the private goods-producing sector, which includes manufacturing, and the private services-producing sector. The industry distribution of imported BPT services is similar to that for all imported purchased services, but there are some important differences (table 8.10). Private industries account for a larger share of the imported BPT services, and these services are more heavily concentrated in the goodsproducing sector, especially in durable goods manufacturing.

As with total purchased services, a measure of the import intensity of outsourcing can be calculated by dividing imported BPT services by all purchased BPT services. This measure increased from 2.1 percent in 1997 to 2.7 percent in 2004 (table 8.11). While the import intensity of outsourcing is not as high as that for all imported purchased services, it has demonstrated a steady if irregular upward trend over the period. This trend appears for both the goods-producing and the services-producing sectors. For the goods-producing sector, the import intensity of outsourcing increased from 3.1 percent to 4.0 percent. For the services-producing sector, it increased from 2.0 percent to 2.8 percent. Among the three largest private users of outsourcing services, import intensities were little changed in professional and business services but increased significantly in manufacturing (from 3.8 percent to 4.9 percent) and in finance, insurance, real estate, rental, and leasing (from 3.1 percent to 5.4 percent).

\section{Impact on Output and Value Added}

If U.S. firms did substitute imports of services for domestic production after 2000, then we should observe some effect on the output and value added of the U.S. industries that provide outsourcing services. In BEA's annual industry accounts, nominal and real gross output for the professional and business services sector increased rapidly from 1997 to 2000 but then slowed considerably after 2000 . Real value added in this sector increased more slowly than for all private services industries and GDP. Gross output prices and value added prices also increased more slowly than in the rest of the economy. As a result, the value added share of GDP originating in the outsourcing sector declined after 2000, from 11.6 percent to 11.5 percent. It is not clear, though, how much of this decline was due to the downturn 


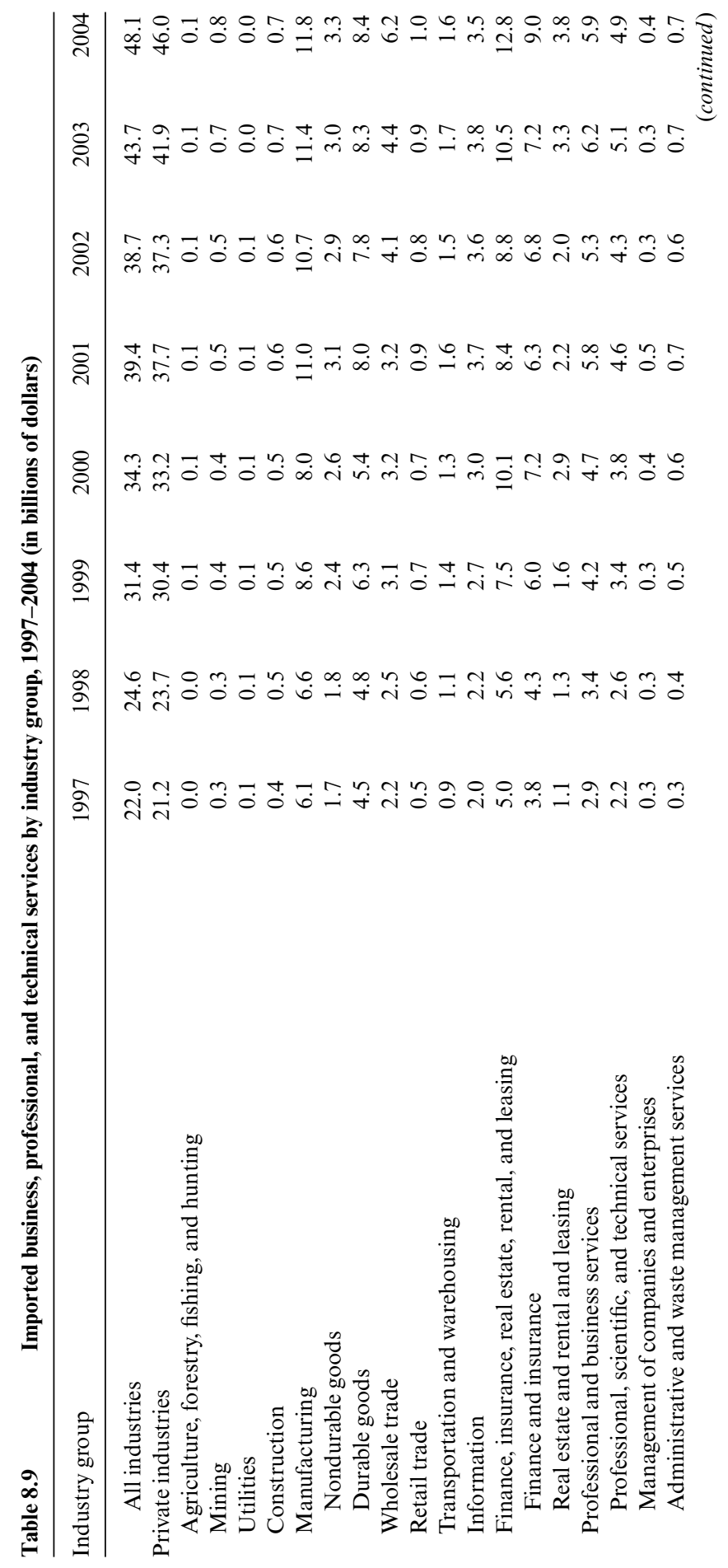




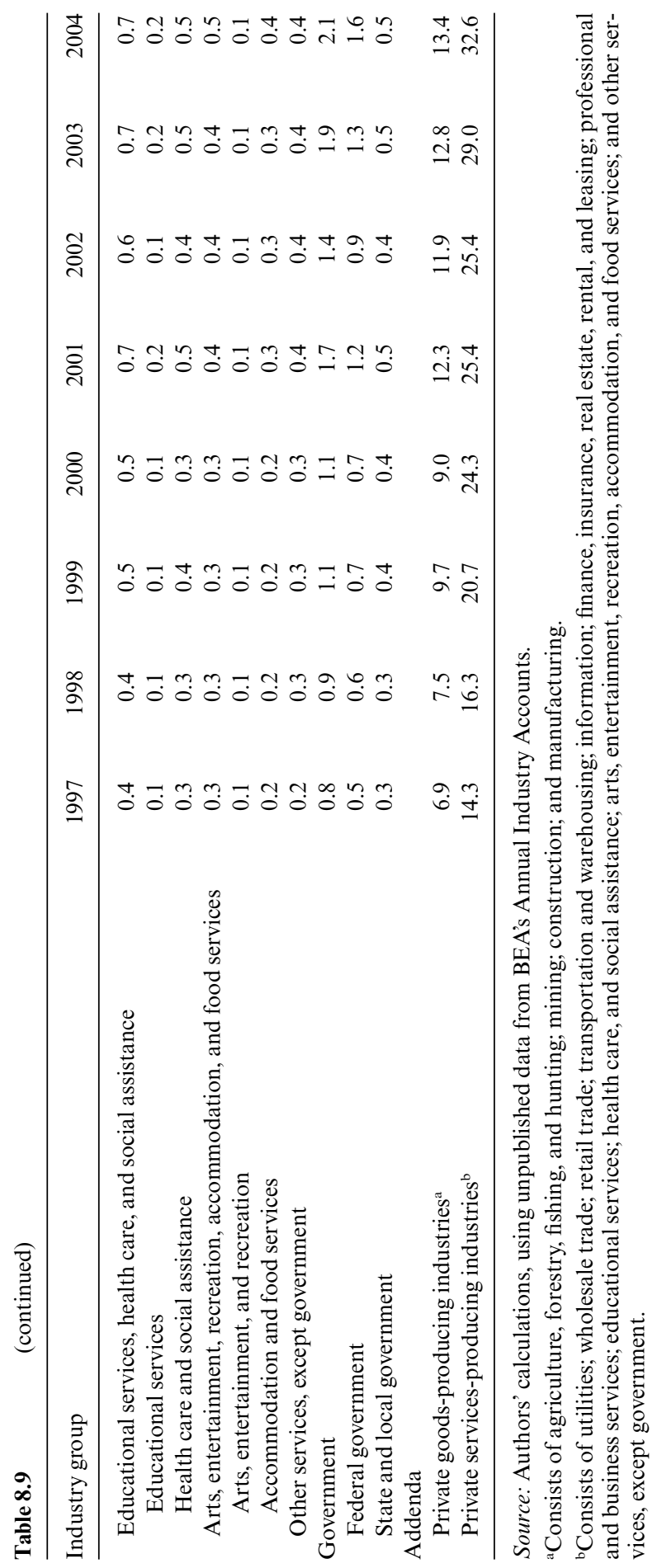




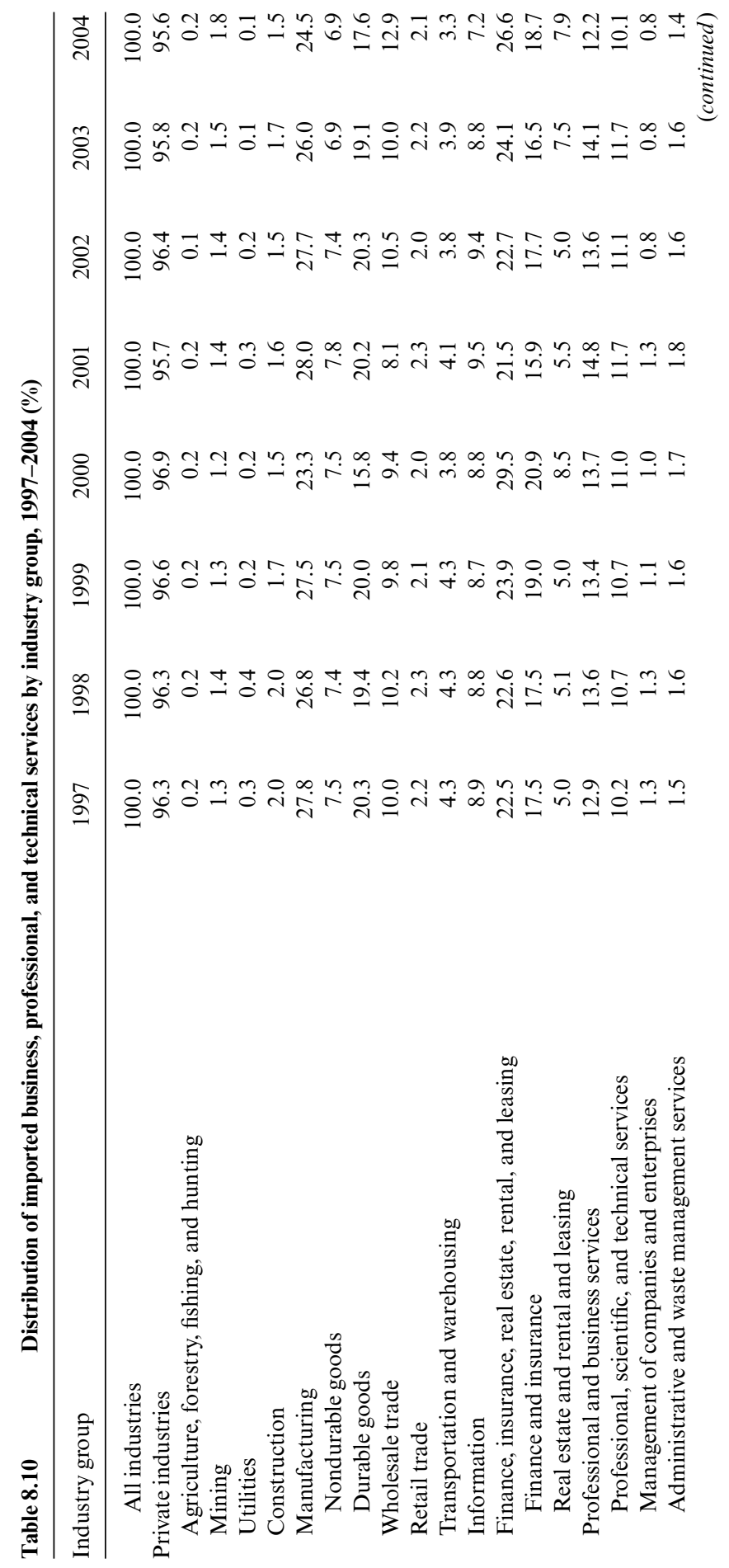




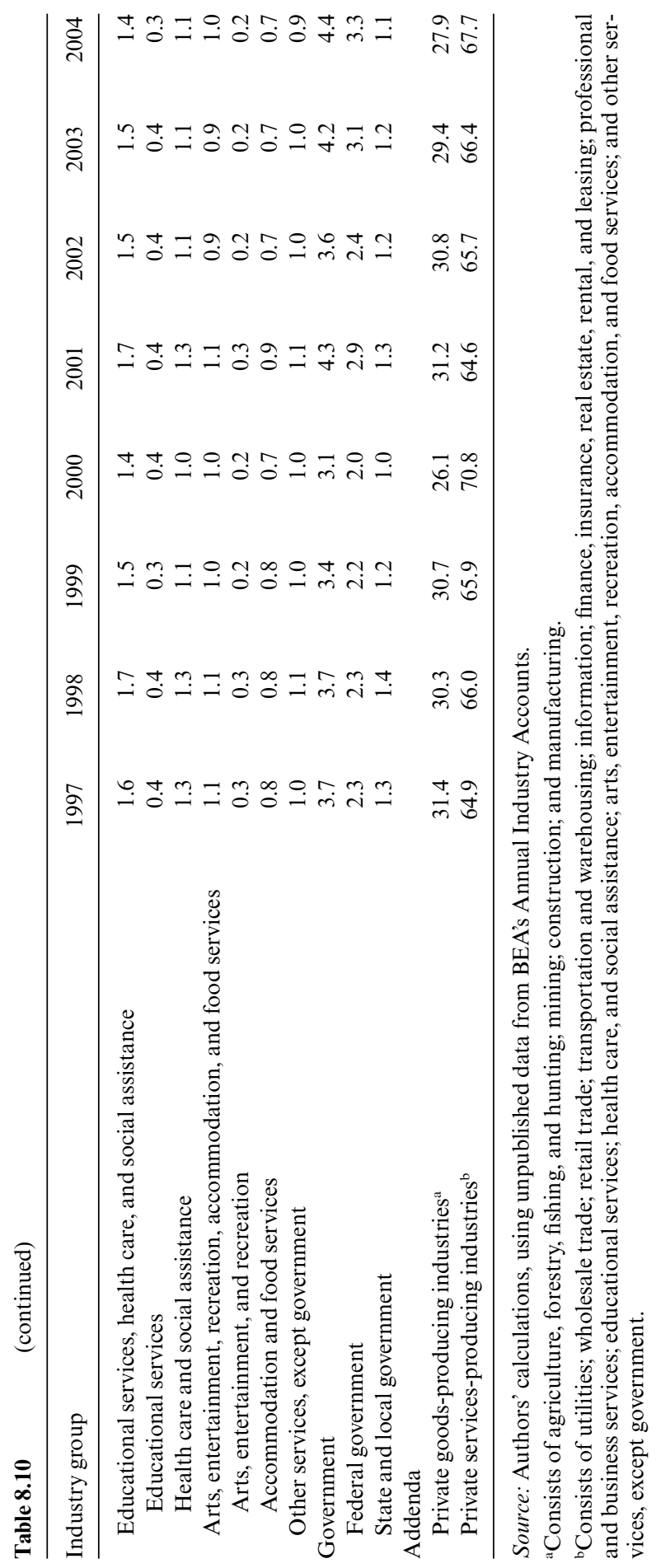




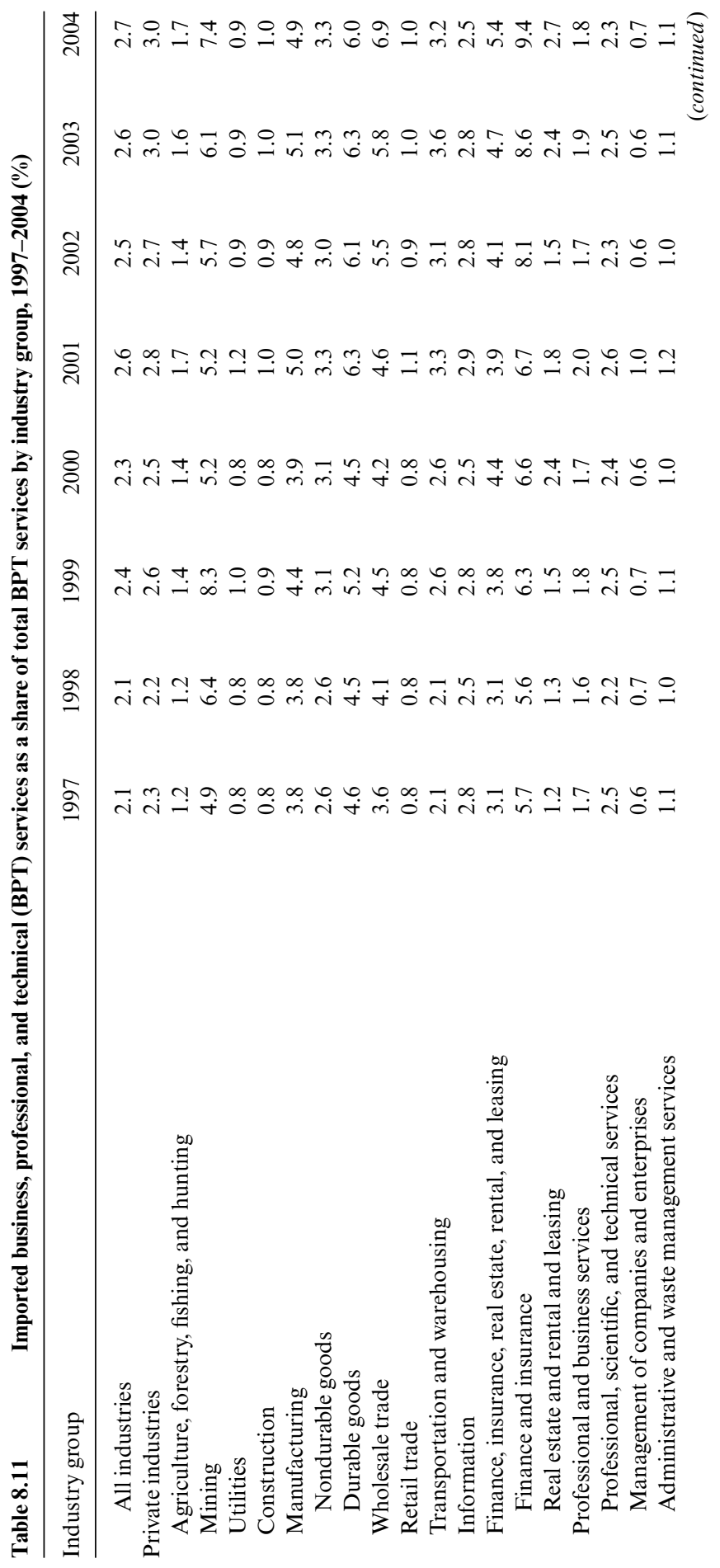




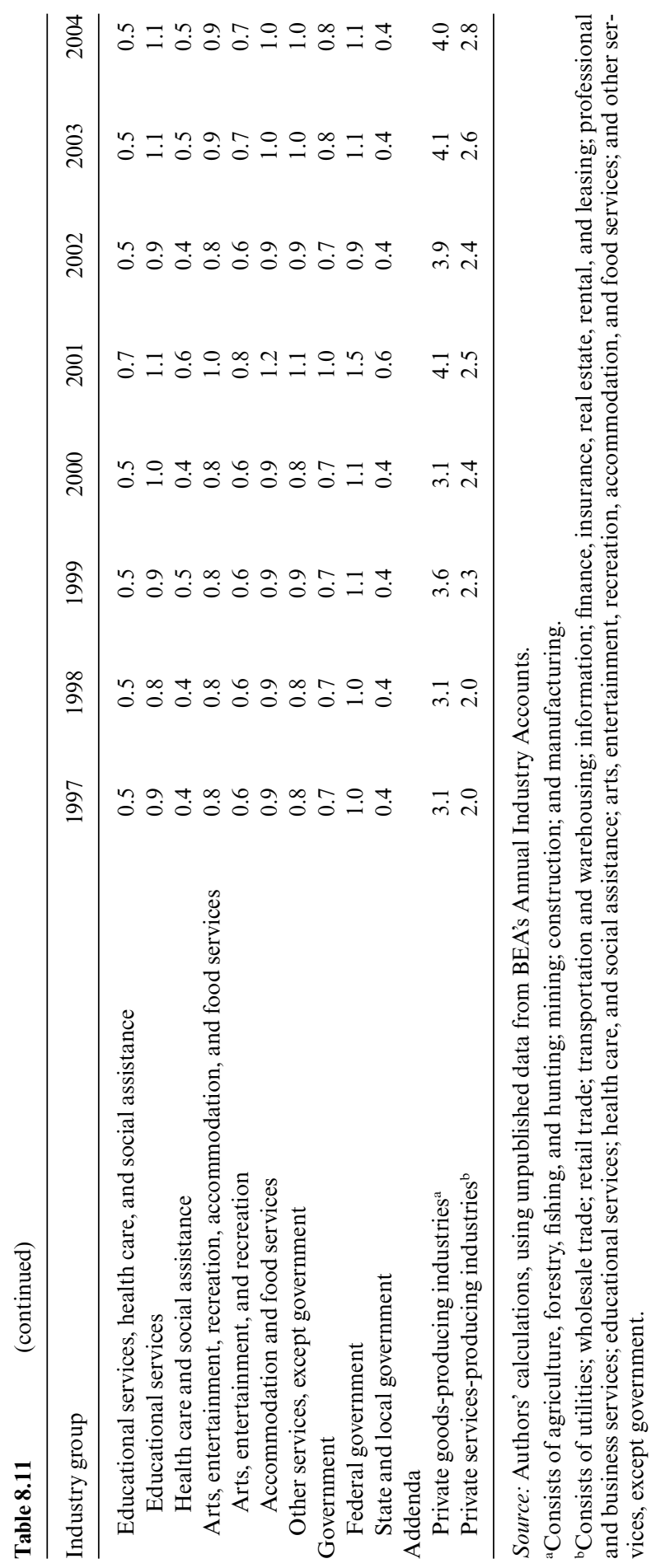


in the overall economy after 2000. For example, during the recession of 1990 to 1991, the outsourcing sector's share of GDP declined from 9.8 percent to 9.7 percent before resuming its upward trend in later years.

As previously shown, the growth of purchased services inputs as a share of gross output for U.S. industries since 1997 has primarily been due to the substitution of purchased services for other inputs, such as energy, materials, and labor, rather than relative price change. Other things equal, this would tend to increase demand for the output of domestic services industries. But we have also seen, within the broad category of purchased services and the narrower category of outsourcing-related BPT services, upward trends in the import intensity of these services. The relatively faster growth of imported BPT services could have come partly at the expense of the domestic outsourcing sector. However, the magnitudes of imported purchased services and imported BPT services are not large enough to explain much of the decline in the domestic outsourcing sector. For example, if nominal gross output (sales) for the domestic outsourcing sector and imported BPT services had continued to grow after 2000 at the same faster rates as in 1997 to 2000, then imported BPT services would have accounted for just slightly more than 2 percent of the difference between potential and actual domestic sales after 2000 .

\subsection{Evaluating the Methodology}

This section presents the findings from evaluating some of the assumptions and procedures used by BEA to prepare the estimates of imported purchased services in the industry accounts. These assumptions and procedures affect the classification of imported services, their distribution by industry, and the deflation of imported purchased services for calculating real value added by industry.

\subsubsection{Classification}

About 70 percent of imported purchased services are classified as noncomparable imports in the industry accounts. Some of these services are clearly noncomparable because they are produced and consumed overseas and are not available for domestic consumption, such as overseas port operations by U.S. air and water carriers and purchases by the U.S. government for overseas operations. However, some other noncomparable services, such as business, professional, and technical services and royalties and license fees, have components that may be comparable to domestically produced services and that could be included in the domestic supply of those services in the industry accounts.

One of the advantages of the current treatment of noncomparable imports for the industry accounts is that data are available from BEA's international investment surveys to assist in the direct assignment of these im- 
ported services to the industry that purchases them, thus improving the overall industry distributions of intermediate inputs and value added. The estimates of noncomparable imports for private industries are obtained directly from BEA's mandatory surveys of the U.S. affiliates of foreign companies and the U.S. parents of foreign companies, which are assigned an enterprise-based industry classification by BEA. Otherwise, some noncomparable imported services would be included in the domestic supply, and their allocation among industries would be based on the assumption of a constant import share for each industry. The Bureau of Economic Analysis will investigate options for reducing the size of imports classified as noncomparable, while retaining the distributional advantages of the current procedures.

\subsubsection{Industry Distribution}

In BEA's industry accounts, estimates of comparable imports by industry, including imported purchased services, are based on the assumption that the economy-wide ratio of imports to total supply (import share) for a comparable good or service applies to each industry that uses the product. This constant-import-share assumption, which is used because of the lack of actual data on the import content of intermediate inputs for individual industries, has been employed in past studies of outsourcing and import substitution for both materials and services (Amiti and Wei provide examples). Variation in the use of comparable imports by industry in the industry accounts thus depends on variation in the use of commodities by industry and in the commodity import share.

Although this assumption is necessary, the import content of specific types of purchased services could vary by industry as a result of factors such as affiliation status, location, product mix, relative prices, or technology. Unfortunately, data have not been available either to test this assumption or to determine the sensitivity of import-related estimates to alternative assumptions. For this chapter, however, we have compiled data on industry-specific purchases of "other private services" and BPT services by combining unpublished industry data from BEA's international accounts on cross-border purchases of services by U.S. firms from both affiliated and unaffiliated parties.

Because multinational companies are typically very large firms, the combined BEA data for U.S. parents and the U.S. affiliates of foreign MNCs account for a significant share of domestic economic activity, especially in the manufacturing sector of the economy. For example, in 2003 the combined value added of U.S. parent companies and U.S. affiliates of foreign companies represented about 25 percent of the value added for all private U.S. industries from BEA's annual industry accounts. For companies classified in manufacturing, the combined value added was 80 percent of the value added for manufacturing in the industry accounts. Because the firms 
that participate in the BEA surveys are enterprises rather than establishments, however, the industry estimates for manufacturing include the operations of nonmanufacturing establishments that are owned by these companies.

Data collected on BEA's direct investment surveys and surveys of transactions between unaffiliated parties can be used to compile estimates of selected types of imported services purchased by U.S. businesses, classified by industry. Industry estimates reflect the consolidated operations of companies that are engaged in more than one industry. The kind of detail available for imported purchased services classified by the industry of the purchaser varies by the source of the data. For example, data are available on industry purchases of royalties and license fees and of other private services (in total) for affiliated transactions, which account for the majority of the import activity. More detailed data are available on purchases of types of BPT services for transactions between unaffiliated parties.

Table 8.12 compares, at highly aggregated levels, the industry distributions of imported BPT services from the industry accounts with those from the international accounts for the year 2002, which is the reference year for

Table 8.12

Distribution of imported business, professional, and technical services by private industry group, 2002 - International accounts and industry accounts (\%)

\begin{tabular}{lcc}
\hline Industry group & International accounts & Industry accounts \\
\hline Private industries & 100 & 100 \\
Manufacturing & 32 & 29 \\
Distributive services $^{\mathrm{a}}$ & 14 & 17 \\
Information & 11 & 10 \\
Finance and insurance & 22 & 18 \\
Professional and business services & 16 & 14 \\
Other industries $^{\mathrm{b}}$ & 6 & 12 \\
Addenda $^{\text {Private goods-producing industries }}{ }^{\mathrm{c}}$ & 33 & 32 \\
Private services-producing industries $^{\mathrm{d}}$ & 67 & 68 \\
\hline
\end{tabular}

Source: Authors' calculations, using unpublished data from BEA's International Accounts and Annual Industry Accounts.

${ }^{a}$ Consists of transportation and warehousing; wholesale trade; and retail trade.

${ }^{\mathrm{b}}$ Consists of agriculture, forestry, fishing, and hunting; mining; utilities; construction; real estate and rental and leasing; educational services, health care, and social assistance; arts, entertainment, recreation; accommodation, and food services; and other services, except government.

${ }^{\mathrm{c}}$ Consists of agriculture, forestry, fishing, and hunting; mining; construction; and manufacturing.

${ }^{\mathrm{d} C}$ Consists of utilities; wholesale trade; retail trade; transportation and warehousing; information; finance, insurance, real estate, rental, and leasing; professional and business services; educational services, health care, and social assistance; arts, entertainment, recreation, accommodation and food services; and other services, except government. 
BEA's next set of benchmark input-output accounts. For transactions between affiliated enterprises, the estimates are based on special tabulations prepared by BEA's International Investment Division (IID). ${ }^{11}$ For transactions between unaffiliated parties, IID provided access to databases that allowed the authors to identify and tabulate BPT services directly. The BPT services in the international accounts include some services that are not included in the industry accounts measure, such as leasing, construction, medical services, miscellaneous disbursements, sports and performing arts, and training services. In recent years, however, the totals compare favorably. For example, in 2002 the sum of BPT services plus affiliated financial services from the international accounts was $\$ 38.9$ billion, and the corresponding sum from the industry accounts was $\$ 38.7$ billion. ${ }^{12}$

Table 8.12 reveals some important differences in the industry distributions of imported BPT services. Shares for the aggregate private-goods producing and private-services producing sectors are very close, but larger differences arise in the distributions within those broad sectors. For example, the share for the manufacturing nondurable goods sector from the industry accounts (not shown) is only about half of that from the international accounts. Within the services sector, shares from the two sets of accounts differ by relatively large amounts in finance and insurance. Some of the differences, of course, are attributable to the fact that the data from the international accounts are classified by industry on an enterprise basis, whereas data from the industry accounts are classified by industry on an establishment basis.

Within both the goods- and services-producing sectors, some large share differences for industry groups are offset at higher levels of aggregation, suggesting the possibility that the differences are attributable largely to differences in classification. These results indicate that the assumptions underlying the industry distributions of imported BPT services in the industry accounts give reasonable results at aggregate levels, but that improvements are possible at more detailed industry levels. The Bureau of Economic Analysis plans to investigate these differences in more detail, with the goal of obtaining improved industry distributions of imported purchased services in the industry accounts. Better grounding of these assumptions is important, not only for understanding the nature of offshore outsourcing, but also for developing more reliable quantity and price indexes for intermediate purchased services by industry.

11. The Bureau of Economic Analysis' data on affiliated transactions by industry from the international accounts are for other private services (OPS) by industry. The OPS differs from BPT services by the inclusion of affiliated financial services, for which the distribution by industry is not separately available. The measure of BPT services from the industry accounts, however, also includes affiliated financial services, which amounted to \$5.4 billion in 2002 . This causes the shares for financial services industries to be higher in both distributions.

12. About $\$ 2$ billion of the total from the international accounts is not allocated by industry. 


\subsubsection{Deflation Procedures}

In BEA's annual industry accounts, a distinction is made between imports and domestic production for the purpose of calculating quantity and price indexes for intermediate inputs as part of the double-deflation method used to calculate real value added by industry. This distinction is made in order to account for differences in the behavior of prices for imported and domestic products when separate price indexes are available. For example, BEA uses a wide variety of price indexes compiled by the BLS International Price Program to deflate merchandise imports in the NIPAs. A composite price index for an intermediate input commodity is computed as a weighted average of its domestic and import price indexes. The weight for the import price index is the share of imports in the total supply of the commodity, and this share is assumed to not vary by industry. This is the same constant-import-share assumption that was used to prepare the annual import matrices for comparable imports.

For imported services, the same deflators that are used to deflate the imported services categories in the NIPAs are also used to deflate the corresponding commodities in the annual industry accounts. For comparable services imports, BEA uses BLS international price indexes, but these are currently available only for passenger fares and for selected components of other transportation services. Other components of transportation services and other comparable nontransportation services are usually deflated with the same price index used to deflate domestic production, such as a BLS producer price index. This procedure assumes that the rate of price change is the same for both imports and domestically produced services. Noncomparable imports that are similar in nature to domestic services, such as financial services, telecommunications, and insurance services, are also deflated with similar domestic price indexes.

Some of the larger categories of noncomparable imports, such as royalties, license fees, and other private services (including noncomparable BPT services) are deflated with a broad measure of price change, the implicit price deflator for final sales to domestic purchasers. Developing price indexes for noncomparable imports is particularly difficult, because large shares of these imports either are a composite of a variety of goods or services or do not represent true arm's length market transactions. For example, direct defense expenditures, travel, and port expenditures abroad consist of a variety of goods and services purchased overseas. ${ }^{13} \mathrm{~A}$ large portion of royalties and license fees and other private services payments to

13. The Bureau of Economic Analysis uses a composite index of foreign consumer price indexes, adjusted for differences in exchange rates, to deflate travel, miscellaneous services, and U.S. students' expenditures abroad. Direct defense expenditures abroad are disaggregated by type of expenditure and deflated with corresponding price indexes for government consumption expenditures. 
affiliated parties are most likely not actual market transactions, and thus may raise internal company transfer-pricing issues. Classifying more of the noncomparable imports, where possible, as comparable may result in better real estimates, even if domestic prices are used for the deflation.

From 1997 to 2004, the KLEMS-based price index for imported purchased services increased slightly faster than the domestic purchased services price index (1.9 percent versus 1.6 percent). Prices for imported services increased more slowly than those for domestic services, however, from 1997 to 2000, when the outsourcing sector's share of GDP was rising. Moreover, for the goods-producing sector, in which the import intensity of purchased services increased the most, prices for imported services declined relative to prices for domestic services over the entire period, but especially from 1997 to 2000. During this period, real imported purchased services grew rapidly relative to real domestic services in the goodsproducing sector. These estimated effects might be larger, however, if more of the imported purchased services - BPT services in particular — could be deflated with true quality-adjusted price indexes. Catherine Mann (2003) and others have commented on the need for better and more detailed price indexes in order to understand the incentives that U.S. firms face when considering outsourcing. The Bureau of Economic Analysis will continue to work with BLS to improve the price indexes used to deflate both domestic and imported purchased services.

\subsection{Summary and Conclusion}

In the industry accounts, imports of intermediate purchased services are relatively small but have steadily increased as a share of total intermediate purchased services, rising from 2.9 percent in 1997 to 3.6 percent in 2004. These services include those that are closely associated with outsourcing but also include other purchased services such as transportation, communications, and finance and insurance. Outsourcing-related services, as defined for this chapter, increased as a share of total purchased services, from 30.8 percent in 1997 to 33.9 percent in 2004. The import share of these outsourcing-related services also increased during this period, rising from 2.1 percent to 2.7 percent.

The small size of these imported services, especially those that are classified as competing with domestic production in the industry accounts, suggests that import competition played only a small role in the slower growth of the domestic professional and business services (outsourcing) sector after 2000. Slower real output growth and employment reductions in this sector are probably better explained by the downturn of 2001 and by sluggish demand for information and communications technology. Using industry and occupation data from BLS, Bednarzik (2005) also concluded 
that services offshoring contributed only modestly to very slow employment growth in the professional and business services sector.

Further study is required to develop a better understanding of how imported services affect industry output, employment, and contributions to GDP. More research is also needed to determine the sensitivity of these results to the assumptions used by BEA for the industry accounts with respect to the classification of imported services and the distribution of these services by using industry. The Bureau of Economic Analysis will continue to review these assumptions and will further investigate company-based data from the international accounts that could help evaluate the assumptions underlying the industry distributions. The bureau will also work with BLS to try to develop improved price indexes for the deflation of imported purchased services in both the national and industry accounts.

\section{References}

Amiti, M. and S.-J. Wei. 2006. Service offshoring and productivity: Evidence from the United States. NBER Working Paper no. 11926. Cambridge, MA: National Bureau of Economic Research.

Bednarzik, R. W. 2005. Restructuring information technology: Is offshoring a concern? Monthly Labor Review 128 (August):11-21.

Borga, M. 2005. Trends in employment at U.S. multinational companies: Evidence from firm-level data. Presented at Offshoring white-collar work: The issues and the implications. Brookings Institution Trade Forum, Washington, D.C.

Government Accountability Office (GAO). 2004. Current government data provide limited insight into offshoring of services. September 2004, GAO-04-932 International Trade, Washington, D.C.: GPO.

Jensen, B., and L. Kletzer. 2005. Tradable services: Understanding the scope and impact of services offshoring. Presented at Offshoring white-collar work: The issues and the implications. Brookings Institution Trade Forum, Washington, D.C.

Kozlow, R., and M. Borga. 2004. Offshoring and the U.S. balance of payments. Presented at Services offshoring: What do the data tell us? Brookings Institution Workshop, Washington, D.C.

Mann, C. L. 2003. Globalization of IT services and white collar jobs: The next wave of productivity growth. International Economics Policy Briefs PB03-11. Washington, D.C.: Institute for International Economics.

Olsen, K. B. 2006. Productivity impacts of offshoring and outsourcing: A review. STI Working Paper 2006/1. Directorate for Science, Technology, and Industry, Organization for Economic Cooperation and Development, Paris.

Strassner, E. H., G. W. Medeiros, and G. M. Smith. 2005. Annual industry accounts: Introducing KLEMS input estimates for 1997-2003. Survey of Current Business 85 (September):31-65.

van Welsum, D., and X. Reif. 2005. Potential offshoring: Evidence from selected OECD countries. Presented at Offshoring white-collar work: The issues and the implications. Brookings Institution Trade Forum, Washington, D.C. 